\title{
Espacialização da temperatura e umidade relativa do ar sob domínio da massa de ar polar atlântica (mpa) num fragmento de floresta em Curitiba (PR)
}

\author{
Spatialization of temperature and humidity of air in the field of polar air \\ mass atlantic in a forest fragment in Curitiba (PR)
}

\author{
Cristiano Alves da Silva'
}

\section{Resumo}

Os processos de urbanização e industrialização são indicadores do alcance de progresso e desenvolvimento, entretanto são apontados como causa de deterioração das áreas verde do meio urbano e da qualidade de vida. Essas alterações podem ser notadas no microclima de uma determinada região com o aumento da temperatura e a diminuição da umidade, causados pela falta de área verde entre outros fatores. A partir desse cenário, o presente estudo analisa a influência das áreas verdes na variação topoclimática de um fragmento de floresta e seu entorno. Nesse sentido, avaliou-se, em escala de abordagem topoclimática, e identificou a influência da temperatura, umidade relativa, direção e velocidade dos ventos ao longo do mês de julho de 2008, face à dinâmica dos tipos de tempo. Os valores das variáveis foram coletados em 9 pontos de monitoramento e comparados entre si e também aos dados da estação meteorológica do INMET. Objetivou-se ainda, estimar os padrões de temperatura e umidade relativa do bosque e da área urbana de entorno influenciado pela Massa Polar Attântica. Após as análises realizadas verificou-se que o aquecimento da superfície, sob determinados tipos de tempo é significativo e indica que a urbanização e as atividades antrópicas interferem nos índices de temperatura e umidade relativa local.

Palavras-chave: topoclima; sistemas atmosféricos; áreas verdes; clima urbano.

\section{Abstract}

The processes of urbanization and industrialization are indicators of the extent of progress and development, however, are pointed out as cause of deterioration of urban green areas and quality of life. These changes can be noticed in the microclimate of a region with increasing temperature and decreasing moisture, caused by lack of green area among other factors. Based on this scenario, this study examines the

I Geógrafo; Mestrando do Curso de Pós-Graduação em Geografia da Universidade Federal do Paraná, UFPR; Endereço: Rua XV de Novembro, 1299, Centro, CEP:80.060-000, Curitiba, Paraná, Brasil; E-mail: dasilva200I@live.com 
influence of green areas in the variation topoclimate in a forest fragment and its surroundings. In this sense was evaluated on a scale of topoclimate approach, and identified the influence of temperature, relative humidity, wind speed and direction throughout the month of July 2008 compared to the dynamics of weather types. The values of the variables were collected at nine monitoring points and compared with each other and to data from the meteorological station INMET. The aim is also to estimate the patterns of temperature and relative humidity of the forest and the surrounding urban area under the effect of mass Polar Atlantic. After the assessments conducted it was found that heating the surface, under certain types of time is significant indicating that urbanization and human activities affect the rates of temperature and humidity place.

Key words: microclimate; atmospheric systems; green areas; urban climate.

\section{Introdução}

A vegetação existente numa determinada área urbana contribui de forma significativa para o estabelecimento de um microclima e possui a capacidade de influenciar os efeitos do clima sobre seus arredores.

A compreensão do microclima e sua interação com o meio é de fundamental importância para o trabalho dos planejadores urbanos (engenheiros, arquitetos, geógrafos entre outros profissionais), o qual pode servir como subsídio para ações de modificação do lugar e definição dos princípios apropriados à boa gestão do espaço construído, com vistas à produção de ambientes adequados ao conforto térmico e saúde da população.

Ao longo das décadas, ignoraram-se as consequências de modificações ambientais que o processo de expansão urbana ocasiona e isso pode ser acurado desde a década de 1940 no bairro Boqueirão em Curitiba. Essa ocupação emergente, embora existindo um zoneamento realizado pela prefeitura, trouxe um adensamento populacional na região, o que reduziu as áreas verdes com tendências a alterações microclimáticas.

Tais fatos impulsionaram o desenvolvimento deste estudo na área militar do 50 Grupo de Artilharia de Campanha Autopropulsado, Unidade do Exército Brasileiro sediada na localidade desde 1949, a qual preserva uma área aproximada de 70 hectares, distribuídos entre área verde e construções, e que possui grande influência no topoclima da área do entorno, sendo, portanto uma reserva natural importante para o bairro e também para a cidade de Curitiba.

É notório que os processos de urbanização indiquem o progresso e desenvolvimento atingido pelo Homem, entretanto isso tem sido assinalado como causa de degradação do meio urbano e da qualidade do ambiente em que a vida se sustenta (LOWRY, 1967).

O bairro Boqueirão tornou-se um exemplo dessa prática, uma vez que ao longo de décadas avançou sobre as matas, aterrou pântanos, edificou uma malha urbana digna de cidades médias no Estado do Paraná, mas como consequência dos diferentes ambientes construídos, criou vários e distintos microclimas. Tal degradação tem como uma das causas a especulação imobiliária e o vertiginoso crescimento da capital paranaense nas últimas décadas, na procura pela expansão de sua malha urbana ao longo dos limites municipais.

Segundo Mendonça (2003, p. 93-120): 
[...] o clima constitui-se numa das dimensões do ambiente urbano e seu estudo tem oferecido importantes contribuições ao equacionamento da questão ambiental das cidades. As condições climáticas destas áreas, entendidas como clima urbano, são derivadas da alteração da paisagem natural e da sua substituição por um ambiente construído, palco de intensas atividades humanas.

O clima em sua dinâmica natural varia em escalas (temporal e espacial) e é classificado dentro de cada unidade para melhor compreensão de suas ações sobre o planeta. Na escala espacial, o clima dividese, hierarquicamente, de maneira didática, conforme exemplificado na figura $1, \mathrm{em}$ diferentes dimensões climáticas: macroclima, mesoclima e microclima. vale ou serra. $\mathrm{O}$ mesoclima se diferencia do macroclima quando surgem modificações locais, regionais e topográficas, em algumas de suas características (MENDONÇA; DANNI-OLIVEIRA, 2007).

De acordo com os estudos de Salati (1983) apud Aguiar e Da Silva (2008), as áreas verdes abrandam as temperaturas e agem como agente absorvedor da energia solar recebida em virtude do albedo apresentado, evitando que parte dessa energia retorne para a atmosfera, aumentando assim a temperatura próxima ao solo. Essas áreas também colaboram para a presença de uma alta umidade no ar, criação de sombras e atuam principalmente na renovação do ar atmosférico através da fotossíntese e, ainda na remoção de poluentes como material particulado (DANNI-OLIVEIRA, 2000).

\begin{tabular}{cccccc}
\hline $\begin{array}{c}\text { Ordem de } \\
\text { grandeza }\end{array}$ & Subdivisões & $\begin{array}{c}\text { Escala } \\
\text { horizontal }\end{array}$ & $\begin{array}{c}\text { Escala } \\
\text { vertical }\end{array}$ & $\begin{array}{c}\text { Temporalidade } \\
\text { dasvariaçóesmais } \\
\text { representativas }\end{array}$ & $\begin{array}{c}\text { Exemplificação } \\
\text { espacial }\end{array}$ \\
\hline Macroclima & $\begin{array}{c}\text { Clima zonal } \\
\text { Clima regional }\end{array}$ & $>2.000$ & $\begin{array}{c}3 \mathrm{~km} \mathrm{a} \\
12 \mathrm{~km}\end{array}$ & $\begin{array}{c}\text { algumas } \\
\text { semanas a vários } \\
\text { decênios }\end{array}$ & $\begin{array}{c}\text { o globo, um } \\
\text { hemisfério, oceano, } \\
\text { continente, mares etc. } \\
\text { reoião natural, }\end{array}$ \\
Mesoclima & $\begin{array}{c}\text { Clima regional } \\
\text { Clima local } \\
\text { Topoclima }\end{array}$ & $\begin{array}{c}2.000 \mathrm{~km} \\
\text { a } 10 \mathrm{~km}\end{array}$ & $\begin{array}{c}12 \mathrm{~km} \mathrm{a} \\
100 \mathrm{~m}\end{array}$ & $\begin{array}{c}\text { de várias horas a } \\
\text { alguns dias }\end{array}$ & $\begin{array}{c}\text { montanha, região } \\
\text { metropolitana, cidade } \\
\text { etc. }\end{array}$ \\
& $\begin{array}{c}10 \mathrm{~km} \text { a } \\
\text { alguns m }\end{array}$ & $\begin{array}{c}\text { Abaixo } \\
\text { de } 100 \mathrm{~m}\end{array}$ & $\begin{array}{c}\text { de minutos ao } \\
\text { dia }\end{array}$ & $\begin{array}{c}\text { bosque, uma rua, uma } \\
\text { edificação/casa etc. }\end{array}$ \\
\hline
\end{tabular}

Figura I. Organização das escalas temporal e espacial do clima

Fonte: Extraído de Mendonça e Danni-Oliveira, 2007, p. 23

Em relação ao mesoclima, costuma-se dizer que é uma escala intermediária entre o macro e microclima. Diversas vezes, utilizase nessa classificação o termo topoclima, ou seja, terminação utilizada para designar um mesoclima onde a topografia constitui um dos critérios principais de identificação, como por exemplo, o clima de um planalto,
Também, os autores apresentam resultados comprovando que a floresta atua significativamente no rebaixamento das temperaturas, melhorando a qualidade do ar local e em contrapartida, demonstram que as áreas sem cobertura vegetal comprometem a qualidade do ar, fazendo com que as temperaturas sejam mais elevadas nessas áreas. 
Conforme Monteiro (1975), as formações vegetais no aglomerado urbano são vistas como focos de purificação do ar, as quais exercem uma importante função pela riqueza das combinações dos seus atributos na qualidade de vida ambiental. Devem, portanto, ser elementos obrigatórios para as cidades, dados a importância e benefícios ofertados pela vegetação na manutenção das boas condições ambientais urbanas.

Segundo Katzschner (1997), apud Mendonça e Assis (1999), o estudo do clima urbano torna-se, quando explorado corretamente, um instrumento para o planejamento das cidades, pois considera a circulação do ar e as condições térmicas como aspectos relevantes para o chamado "clima urbano ideal" durante o processo de crescimento das cidades.

A partir desse cenário, o presente estudo pretendeu identificar e avaliar o topoclima no interior de um fragmento de floresta, localizado na cidade de Curitiba, tomando por base os dados levantados em trabalho de campo, durante o mês de julho de 2008, bem como analisar a importância de uma área vegetada no topoclima urbano.

\section{Materiais e Métodos}

A área pesquisada está situada no bairro Boqueirão, quadrante sudeste da cidade de Curitiba (PR), nas coordenadas geográficas -49॰14'22"(longitude) e -2530'25” (latitude). É caracterizada por ser uma Unidade Militar, pertencente ao Exército Brasileiro e denominada $5^{\circ}$ Grupo de Artilharia de Campanha Autopropulsado (5 GAC AP), instalada na localidade desde 1949. A região pesquisada ocupa uma área aproximada de 70 hectares, e situa-se a $12 \mathrm{~km}$ do centro da cidade (Figura 2).

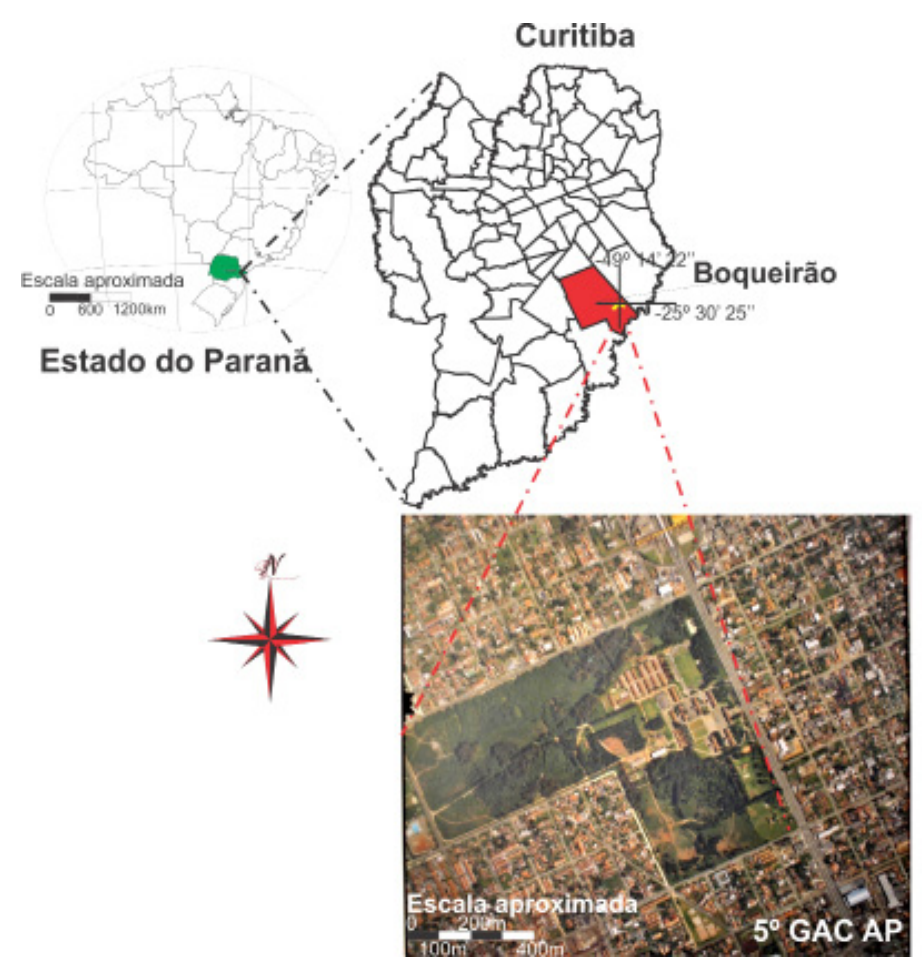

Figura 2. Localização da área de estudo

Fonte: IBGE e Fotografia aérea da Esteio Aerolevantamentos 1999.

Organizado pelo autor 
$\mathrm{Na}$ caracterização do relevo, a área apresenta uma diferença de altitude de 30 metros, conforme se observa no mapa de hipsometria (Figura 3). Os solos são classificados como cambisolos húmicos, de textura argilosa, substrato basáltico e de teor ácido (EMBRAPA, 1999).

O perímetro dessa área verde aproximase dos $4 \mathrm{~km}$ e possui uma vasta cobertura vegetal, sendo constituída por formações nativas, plantações e espécies exóticas e invasoras. Nas formações nativas destacamse fragmentos de Floresta Ombrófila Mista sendo que o restante da área é ocupada por estradas, áreas de treinamento militar, pavilhões e pequenas áreas de cultivo de hortaliças.

A hidrografia da área (Figura 4) destaca-se por apresentar, no interior do bosque, um dos afluentes, sem denominação, do rio Belém, bem como nascentes que abastecem os açudes e áreas alagadiças e dão volume ao córrego que deságua no rio referido.

Esse experimento está baseado na proposta geral de Monteiro (1975), acerca da abordagem rítmica, a qual objetiva compreender a disposição climática aplicada à área de estudo, ou seja, a relação entre a atmosfera e a caracterização da estrutura urbana.

Como um sistema aberto e complexo, o clima urbano apresenta-se na cidade como um componente essencial na transformação que ocorre na atmosfera urbana, através das modificações pela urbanização, e acontecimentos como as ilhas de calor e as inversões térmicas (MONTEIRO, 1975).

Nesta pesquisa abordou-se a dinâmica da temperatura (T) e umidade relativa (UR) no interior de um fragmento de floresta e se analisou a importância de uma área vegetada na variação da $T$ e UR da área urbana de

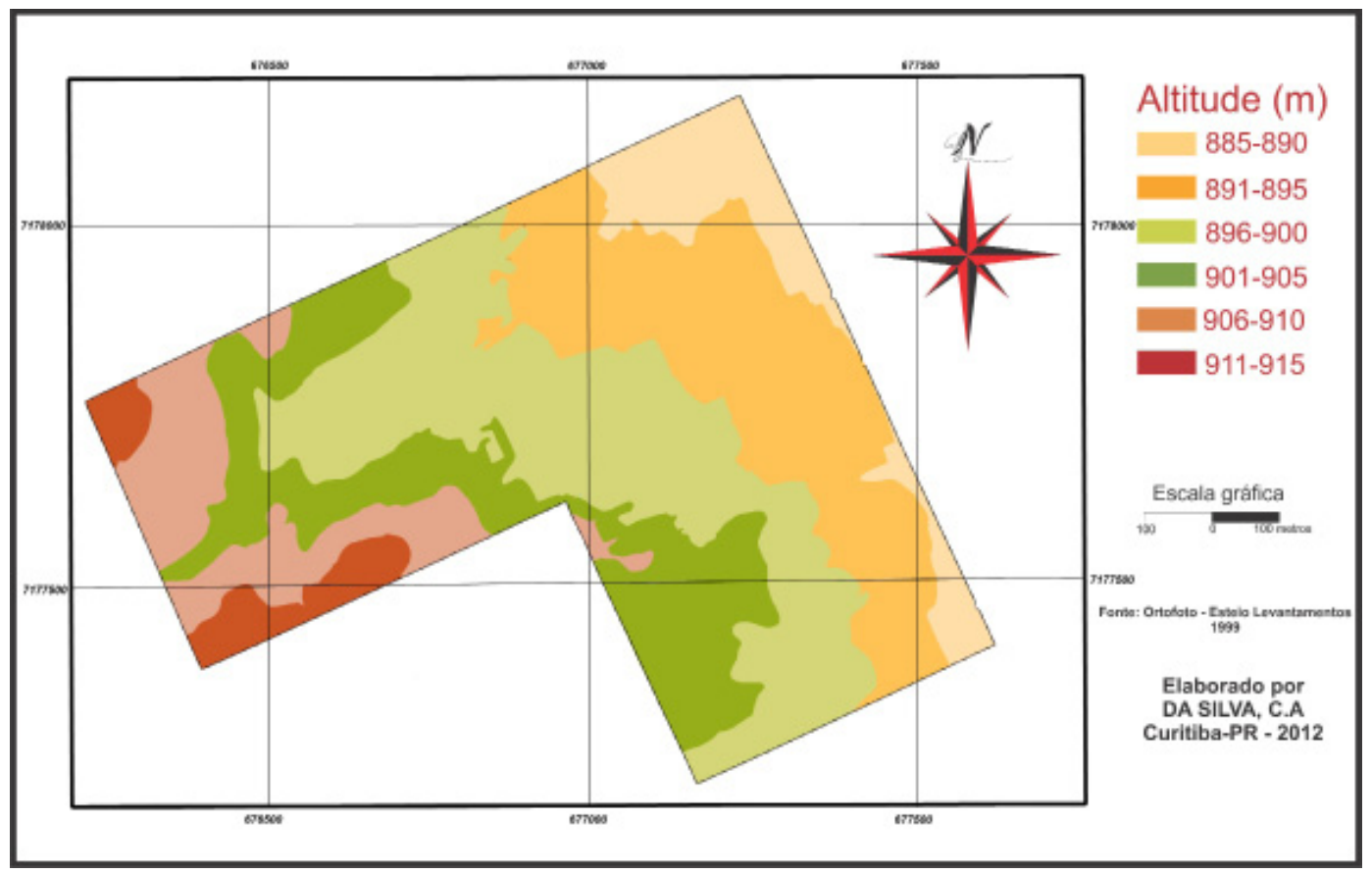

Figura 3. Carta de hipsometria 


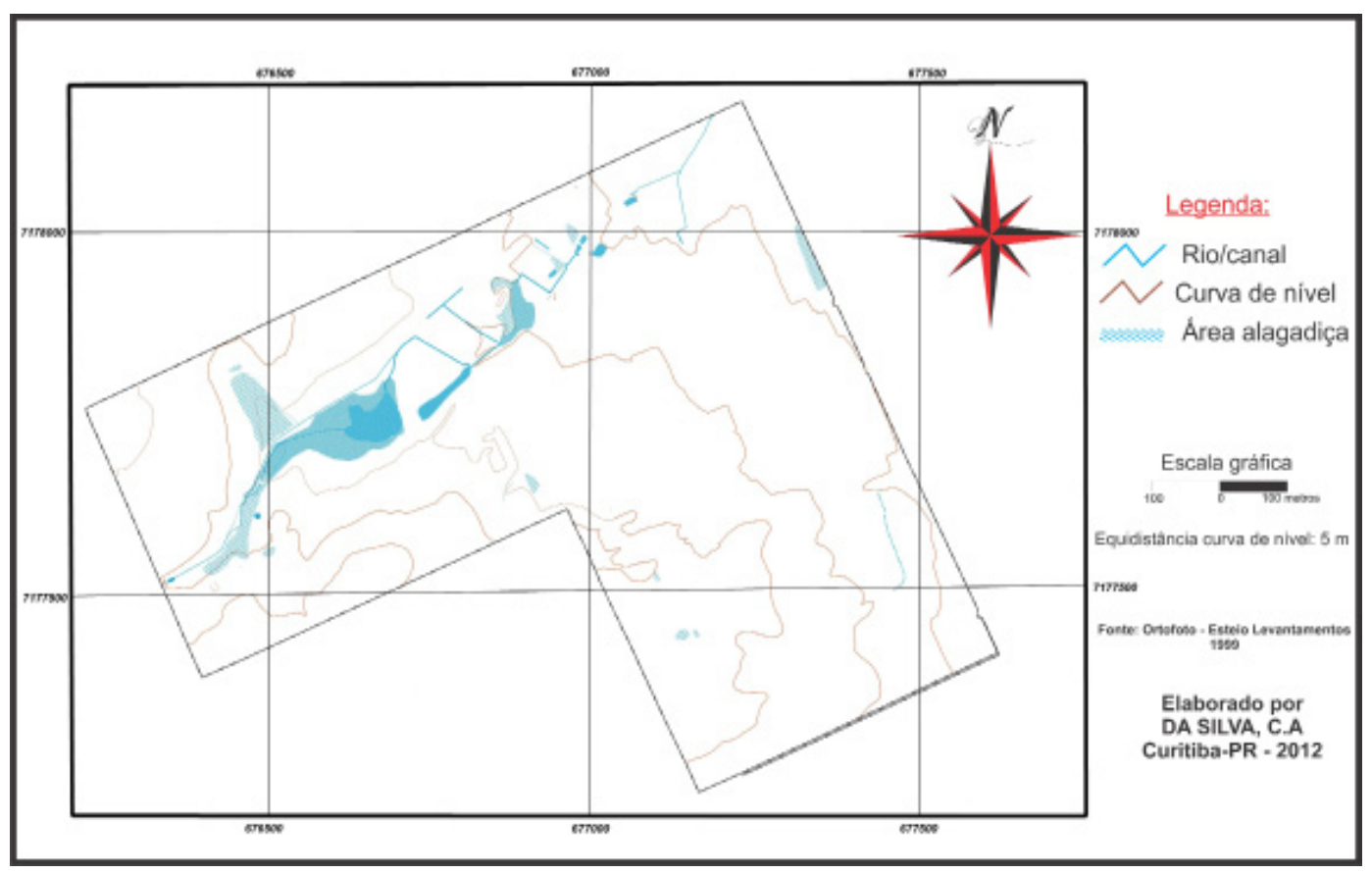

Figura 4. Rede hidrográfica existente na área que colabora para a manutenção do ecossistema

entorno, visando valorizar o uso desse recurso na implantação e manutenção de áreas verdes nas cidades.

Embora a escala espacial seja microclimática, a opção foi para um tratamento topoclimático, em vista a escala temporal, com a realização de três medidas diárias, correspondente ao horário sinótico da estação oficial (12, 18 e 00 UTC) em nove pontos do sítio proposto para estudo, através de medições móveis. A articulação com a escala local foi comparada com os dados da estação meteorológica oficial da cidade de Curitiba, a Estação do Instituto Nacional de Meteorologia (INMET) localizada no Centro Politécnico da Universidade Federal do Paraná.

A variação temporal e espacial descrita neste trabalho é baseada na atuação do sistema atmosférico denominado Massa Polar Atlântica (MPA) e seus respectivos tipos de tempo que ocorreram no sítio estudado, utilizando-se da análise rítmica como principal ferramenta para indicá-los.

Os produtos gerados foram confrontados com as informações coletadas no Instituto Nacional de Meteorologia (INMET) e analisados com o auxílio das imagens do satélite Goes (10 e 12) no canal Infravermelho, fornecidos pelo Sistema Meteorológico do Paraná (SIMEPAR) e Centro de Previsão de Tempo e Estudos Climáticos (CPTEC).

\section{Escolha dos Pontos de Monitoramento}

Delimitada a área, foram selecionados no interior da floresta e entorno, nove pontos para a realização da medição dos elementos climáticos (Figura 5). Os critérios utilizados para a seleção foram determinados pelas características locais, de modo a contemplar 


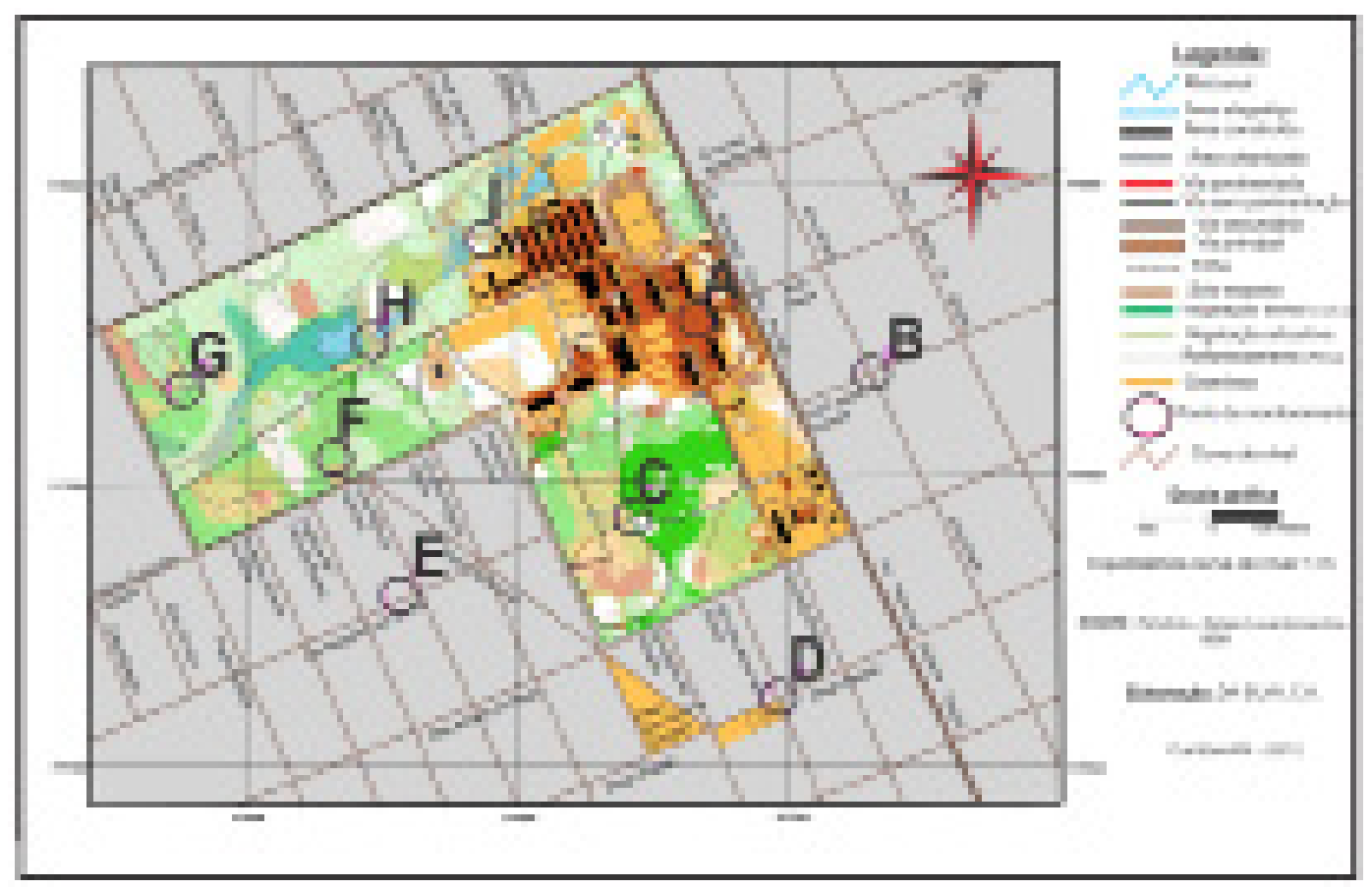

Figura 5. Caracterização da área de pesquisa ressaltando os pontos de monitoramento, o uso e ocupação do solo e também o arruamento da área de entorno

a medição dos elementos climáticos tanto de uma parcela da área construída quanto vegetada.

Apresenta-se na sequência, uma descrição dos locais escolhidos para a coleta dos dados em campo, com informações complementares e de interesse para este trabalho.

Ponto A - Situado no interior do aquartelamento e localizado a uma altitude de 893 metros, possui como cobertura do solo uma calçada cimentada e rua asfaltada na frente da edificação. Tal construção possui três metros de altura e tem a cor branca predominante em sua constituição.

Ponto B - Situado no cruzamento das ruas Anne Frank com a Prof ${ }^{a}$ Joanita B. Passos, no lado externo da área cercada do quartel, esse ponto de monitoramento foi selecionado para justificar e apurar a influência da área vegetada com o entorno do fragmento de floresta, pois se acredita na possibilidade de ser o ponto com maiores índices de temperatura e de menor umidade relativa por estar numa região densamente urbanizada com casas, vias pavimentadas e ausência de vegetação no local, sendo uma rua de movimento moderado nos períodos da manhã e noite e intensamente no horário das 15 horas.

Ponto C - Tal ponto encontra-se no entroncamento de vias não pavimentadas do interior do aquartelamento, cercado de vegetação de grande dossel e próximo de uma área com solo exposto.

Ponto D - No cruzamento das ruas Diogo Mugiatti com Januário Alves de Souza, o ponto $\mathrm{D}$ está afastado aproximadamente 150 metros da orla da vegetação do $5^{\circ} \mathrm{GAC}$ AP. A medição foi realizada sobre uma 
superfície gramada de uma residência no cruzamento das vias. Em frente ao ponto, está o campo de futebol do SESI Boqueirão, no qual em sua borda existe uma grande variedade de árvores fazendo com que o local tenha uma boa ventilação e sombreamento, principalmente as 15 horas. São ruas de grande movimento durante a manhã e tarde e de pequena intensidade as 21 horas. Por ser uma região plana, e com um potencial corredor de casas, o vento é de intensidade moderada na região.

Ponto E - Existem nesse local casas, geralmente de dois pavimentos e de alvenaria, muito próximas uma das outras fazendo com que a insolação e ventilação não sejam a mais adequada, mas os equipamentos foram instalados sobre área gramada e em local bem ventilado, num local julgado apropriado $(1,50$ $\mathrm{m}$ do solo) para a correta leitura dos dados, conforme normas da OMM.

PontoF-Esse ponto de monitoramento está localizado próximo à rua e orla da vegetação no interior da área militar. Tal local foi escolhido com o intuito de ser um ponto intermediário entre a zona urbanizada e o interior da floresta. Possui em seu entorno, vias não pavimentadas, árvores de grande porte e uma construção que abriga as caixas d'água que abastecem todo o aquartelamento. No local a insolação é incisiva no período da manhã, e à tarde a situação se inverte, pois a área fica sujeita ao sombreamento que a vegetação proporciona ao local.

PontoG-Esse ponto de monitoramento localiza-se numa trilha de acesso ao interior da vegetação. Existe no local a presença de uma área de aproximadamente $100 \mathrm{~m}^{2}$ com solos expostos, tangentes à trilha. O local foi selecionado para abranger a totalidade da área de estudo, sendo o ponto mais distante da entrada. Possui em seu entorno, vias com e sem pavimento, árvores de grande e médio porte além de vegetação arbustiva. Duas ruas principais de acesso ao bairro estão próximas à localidade do ponto $\mathrm{G}$, passando em média, durante o horário das medições 25 carros por minuto.

Ponto H - Localizado a beira de uma via não pavimentada é o ponto próximo ao centro da área. Foi escolhido por estar entre áreas úmidas de banhado, córregos, trilhas e sofrer os efeitos da vegetação.

Ponto I - Assim como o ponto $\mathrm{H}$, essa estação de monitoramento I está inserida quase ao centro da área, mas como característica principal assinala o limite entre a floresta e a área construída. Foi selecionado justamente por estar na divisa de tais áreas confluentes, sendo possível verificar a variabilidade dos elementos climáticos estudados. Não há vias de acesso, apenas um descampado com vegetação gramínea na entrada da área.

Estação do INMET - A Estação do Instituto Nacional de Meteorologia (INMET) está localizada no Centro Politécnico da Universidade Federal do Paraná, no bairro Jardim das Américas. Tal estação encontra-se instalada na parte alta do campus, sobre uma superfície gramada e com pouca vegetação ao seu entorno, predominando na área árvores de grande porte, distantes uma das outras, e também poucos arbustos, não interferindo na medição das variáveis. Ao contrário, a estação localiza-se próxima a fontes de calor (antrópica e natural), áreas com alta refletividade e absorção de radiação, como por exemplo, a proximidade (100 metros) da BR-277, com alto tráfego de automóveis e caminhões, ruas de acesso ao campus (asfaltadas e outras com paralelepípedos), áreas com gramíneas (alta absorção) podendo influenciar no microclima da estação e consequentemente nos dados obtidos. 


\section{Coleta dos Dados}

Tendo em vista a influência da radiação solar e os índices de albedo, as medições foram realizadas diariamente nos mesmos locais designados, para evitar diferença dos locais de coleta dos dados.

Antes de iniciar as medições, diaa-dia, fez-se a inspeção dos equipamentos tendo em vista a validade dos dados. $\mathrm{O}$ trabalho em campo iniciou no dia $1^{\circ}$ de julho de 2008 e finalizou no dia 31 do mesmo mês, totalizando 31 dias, com três medições diárias, em nove pontos de monitoramento distintos.

Foram calculadas inicialmente as médias das temperaturas, umidades e velocidade dos ventos, diárias e horárias, bem como identificado as máximas e mínimas das variáveis de cada ponto de monitoramento conforme as equações a seguir:

$$
T m=\frac{t_{P 1}+t_{P 2}+\ldots+t_{P n}}{P n}
$$

Tm: Temperatura média do ponto em questão para determinado horário $(09,15$ ou 21 horas);

$t_{P n}$ : temperatura do mesmo ponto para determinado horário e dia,

$P n$ : leituras realizadas.

$U R m=\frac{u r_{P 1}+u r_{P 2}+\ldots+u r_{P n}}{P n}$

onde:

$U R m$ : Umidade relativa média do ponto em questão para determinado horário $(09,15$ ou 21 horas);

$u r_{P n}:$ Umidade relativa do mesmo ponto para determinado horário e dia,

$P n$ : leituras realizadas.

$V e l_{\text {Vento }}=\frac{V e l_{P 1}+V e l_{P 2}+\ldots+V e l_{P n}}{P n}$ onde:

$V_{\text {vento }}$ : Velocidade do vento do ponto em questão para determinado horário $(09,15$ ou 21 horas);

$\mathrm{Vel}_{P n}:$ Velocidade do vento do mesmo ponto para determinado horário e dia,

$P n$ : leituras realizadas.

O cálculo das diferenças médias entre os pontos de monitoramento e o INMET, para cada variável e horário, também foi calculado baseado na equação seguinte:

$\Delta T_{\text {horírio }}=\boldsymbol{t}$ ponto $-\boldsymbol{t}$ INMET

onde:

$\Delta T_{\text {horário }}:$ Variação da temperatura do ponto em questão para determinado horário (09, 15 ou 21 horas);

tponto: temperatura do ponto em análise e, tINMET: temperatura fornecida pela estação do INMET no mesmo horário.

$\Delta U R_{\text {horraro }}=$ ur ponto - urINMET

onde:

$\Delta U R_{\text {borário: }}$ : Variação da umidade relativa do ponto em questão para determinado horário (09, 15 ou 21 horas);

ur ponto: umidade relativa do ponto em análise e,

ur INMET: umidade relativa fornecida pela estação do INMET no mesmo horário.

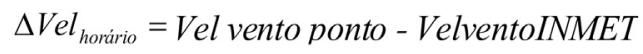

onde:

$\Delta V l_{\text {borário }}$ : Variação da velocidade do vento do ponto em questão para determinado horário (09, 15 ou 21 horas);

Vel vento ponto: velocidade do vento do ponto em análise e,

Vel vento INMET: velocidade do vento fornecida pela estação do INMET no mesmo horário. 
As diferenças médias de temperatura, umidade e ventos de cada ponto foram comparadas com os registros da estação do INMET (estação padrão para a cidade de Curitiba), para cada horário e dia, e foram discutidas face aos tipos de tempos atuantes na região.

Assim, quando os forem negativos, significam que os valores do INMET foram maiores e vice versa para o registro das temperaturas. $\mathrm{Na}$ análise da $\Delta U R$, os valores positivos encontrados significam que os índices são superiores ao da estação padrão da cidade, portanto um ambiente mais úmido.

Para a coleta da umidade relativa do ar, foi utilizado um psicrômetro, constituído por dois termômetros idênticos, dispostos lado a lado, sendo um de bulbo seco e outro de bulbo úmido.

Para a medida da velocidade e direção dos ventos foi utilizada uma bússola, um suporte contendo uma fita de cetim e escala de Beaufort. Inicialmente, com a bússola, fez-se uma indicação do Norte no terreno, de modo a orientar o suporte contendo a fita de cetim, para saber a direção dos ventos.

A escala de Beaufort foi utilizada para a avaliação da velocidade e um GPS da marca Garmin, serviu de modo a confirmar as coordenadas dos pontos de monitoramento.

\section{Resultados e discussões}

$\mathrm{Na}$ cidade de Curitiba, a principal massa de ar atuante no mês pesquisado (julho) foi a Polar Atlântica (mPA) a qual possui como características ser fria e relativamente úmida, podendo rebaixar a temperatura para valores negativos.

$\mathrm{Na}$ análise dos dados associados à mPA, observou-se no dia 4, após o desvio de um sistema frontal (FPA), a presença de uma nova massa de ar atuante (Figura 6) influenciando o declínio das temperaturas.

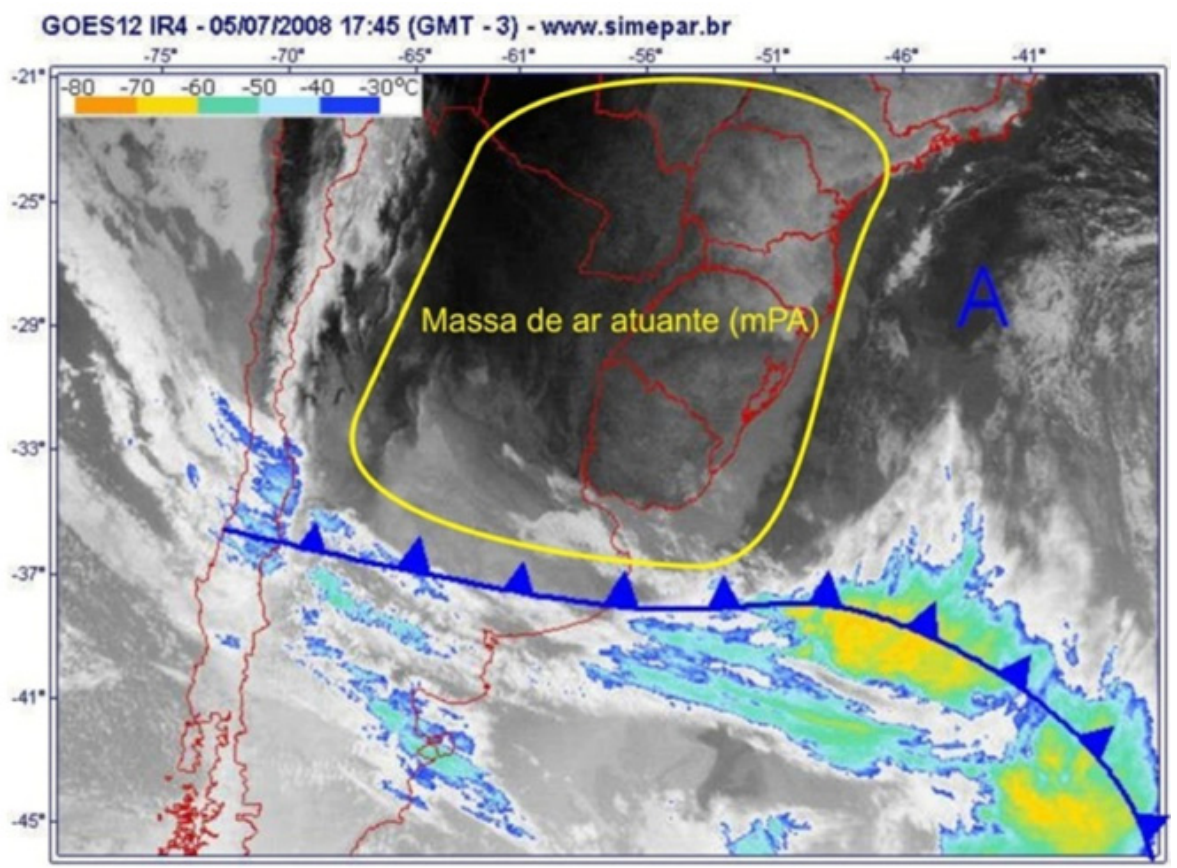

Figura 6. Imagem do Satélite GOES 12 - Canal Infravermelho - do dia 5 descreve a atuação da mPA Fonte: Simepar e modificado pelo autor (2008) 
A análise em conjunto do gráfico, apresentado na figura 8 e das isotermas das 9 horas (Figura 7) revelam que para esse tipo de tempo as temperaturas diminuíram da área urbanizada para a área vegetada. Nitidamente, vê-se a curva ascendente realizada pelo gráfico nos pontos $\mathrm{A}$ e $\mathrm{B}$ e também nos pontos $\mathrm{D}$ e $\mathrm{E}$, pois ambos localizam-se próximos a áreas com intenso uso e ocupação do solo, seja no adensamento ou impermeabilização. Ao contrário, nos pontos em que a vegetação se faz presente, a diminuição de temperatura foi maior, como se visualiza no interior da área demonstrada pela figura 7. A variação térmica entre os pontos ( $\mathrm{H} \mathrm{e} \mathrm{I}$ ) quando comparados com o INMET, foi de $3^{\circ}$ a $4^{\circ} \mathrm{C}$, no qual para um tempo em que as temperaturas tendem a ser mínima, tal variação é significativa para a análise das ilhas de frescor existentes no interior da área.

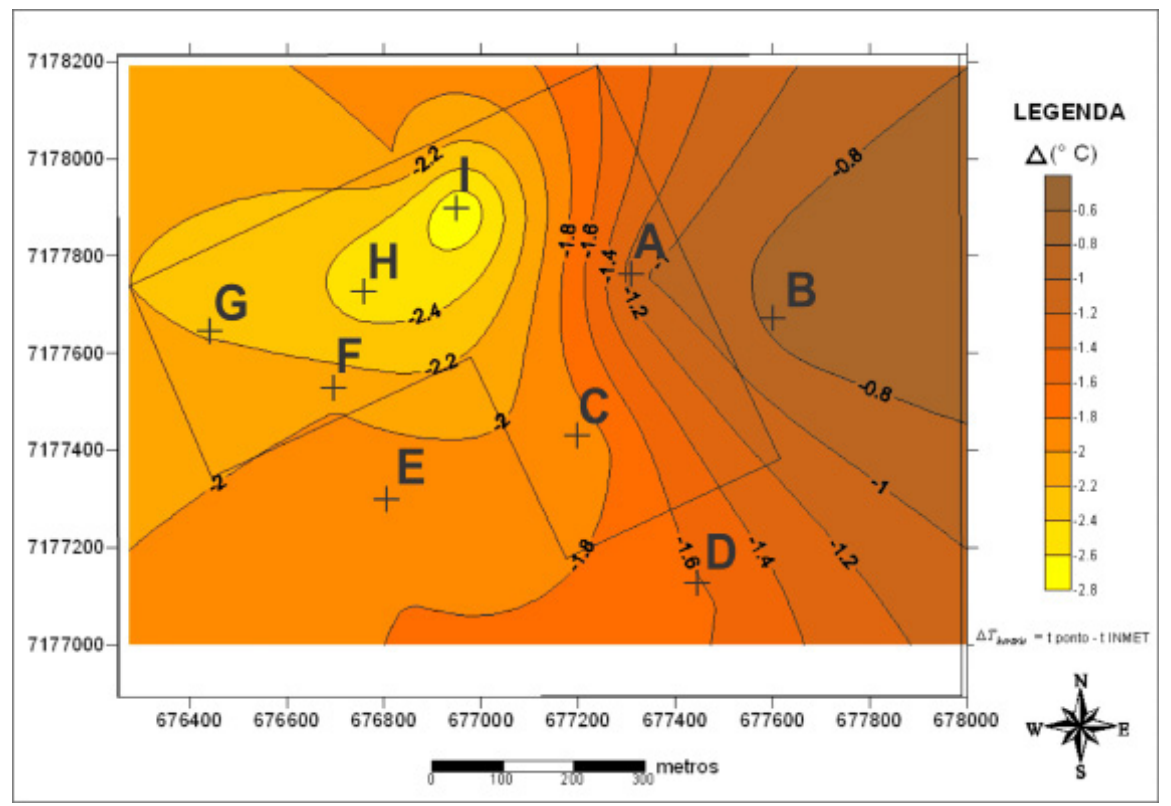

Figura 7. Isotermas associadas à mPA no horário das 9 horas

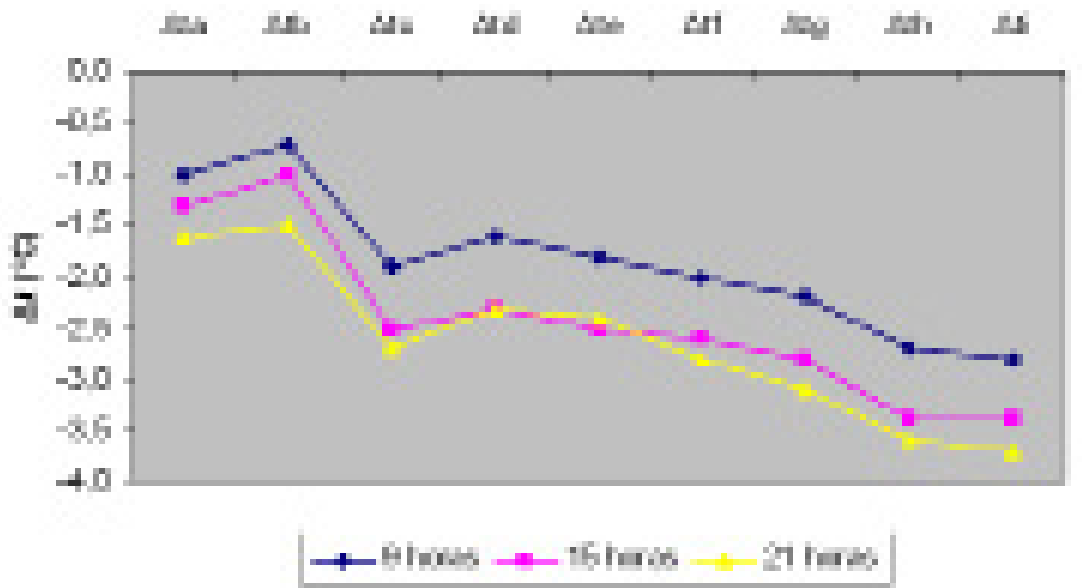

Figura 8. Variação da temperatura associada à mPA 
Os cartogramas a seguir, são representativos das variações de temperatura das 15 e 21 horas (Figuras 9 e 10), os quais demonstraram índices relativamente menores quando comparados com o cartograma das 9 horas. As isotermas da face leste, nesse momento da análise, apontaram para o interior da área do 50 GAC AP, fato decorrente da radiação proveniente do Sol e fontes externas e antrópicas, que favorecem o aumento dos índices de temperatura como por exemplo, a proximidade com a principal via de acesso bairro-centro com alto tráfego de automóveis (45 automóveis/min na média).

Ao redor da área, a vegetação exerceu influência sobre o topoclima local, como se vê

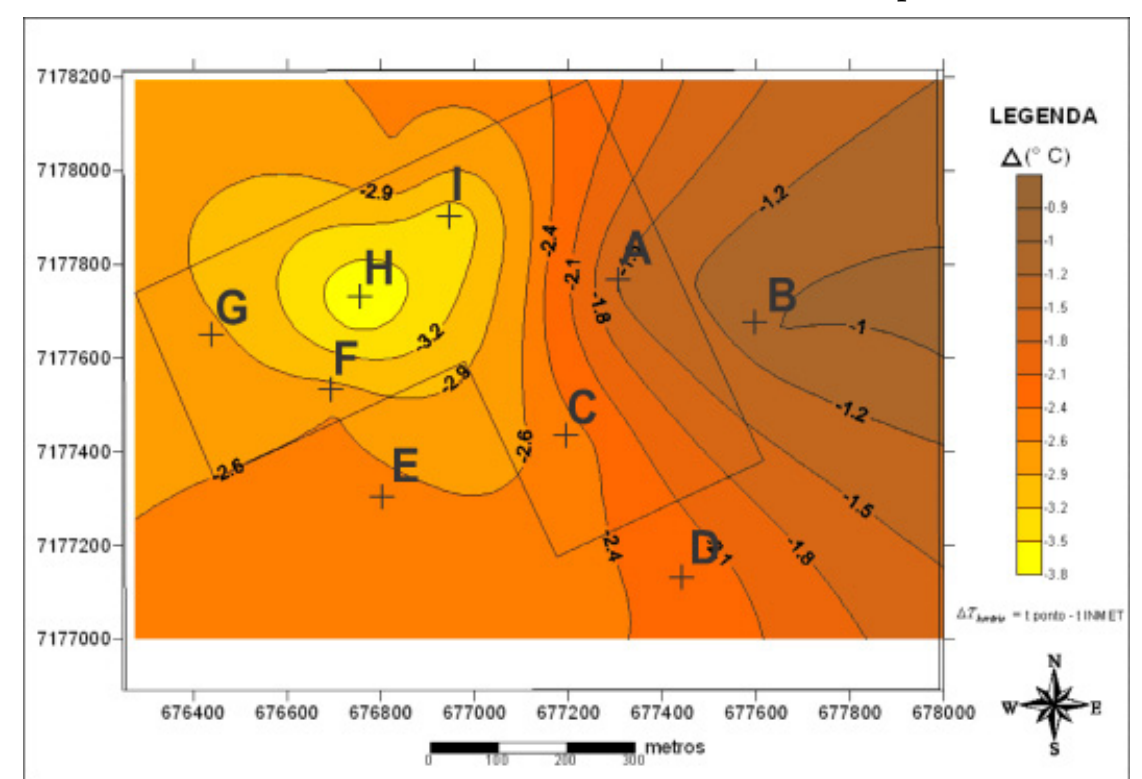

Figura 9. Isotermas associadas à mPA no horário das 15 horas

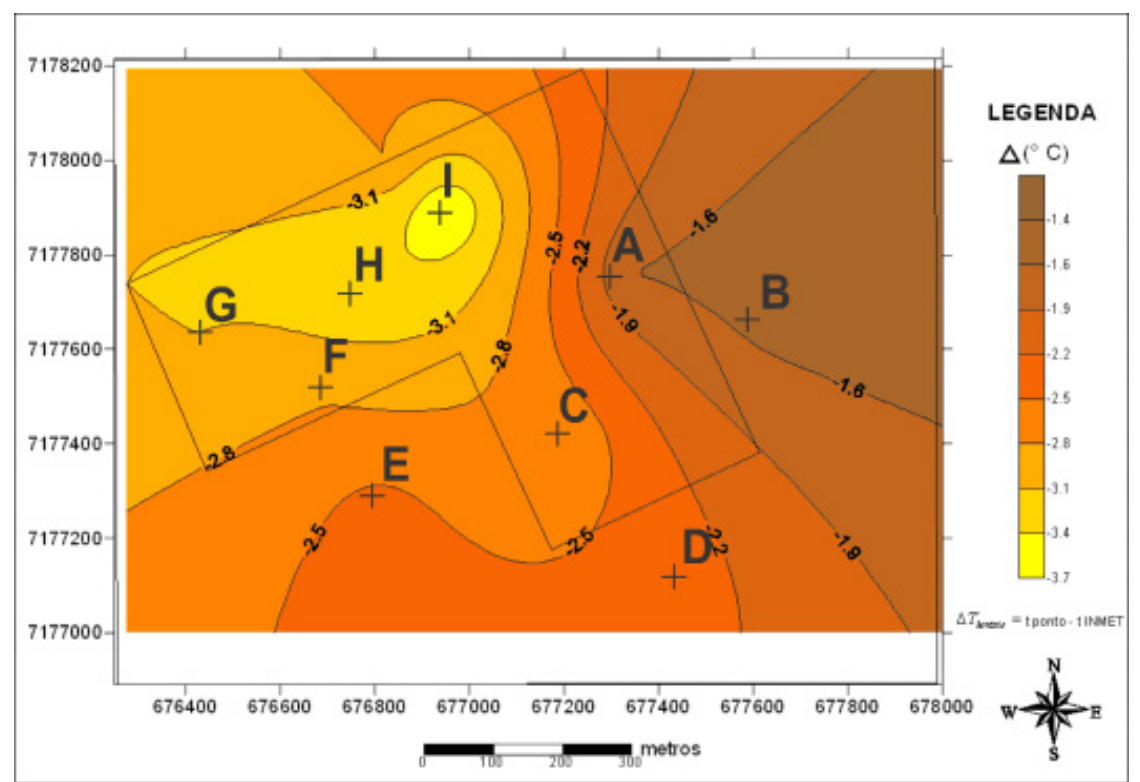

Figura 10. Isotermas associadas à mPA no horário das 21 horas 
nas isotermas da figura 10 , que demonstraram a importância em se manter áreas verdes para auxiliarem na condição climática, amenizando os efeitos de calor.

A umidade disponível em níveis baixos da atmosfera causou frequentemente o surgimento de nevoeiros pela manhã, tal fenômeno é característico na presença de ar estável, ausência de vento e elevada umidade do ar (LOMBARDO, 1985). Conforme é demonstrado no cartograma de umidade relativa associada à $\mathrm{mPA}$ (Figura 11 ), mantém-se uma área de domínio exercido pela vegetação sobre o entorno, no horário das 9 horas, exceto na face leste da área, sendo que tais índices são semelhantes aos da estação padrão, atingindo até $91 \%$ de umidade.

Os nevoeiros permaneceram particularmente por mais tempo nas áreas com vegetação, e ao contrário, em áreas livres, logo com o aquecimento da superfície pela radiação solar, tal fenômeno logo se dissipou.
Com a presença desse tipo de fenômeno registrou-se baixas temperaturas e uma alta porcentagem de UR, com índices que variam de 90 a $94 \%$.

$\mathrm{Na}$ curva do gráfico referente às 15 horas, bem como o representado na figura 12 , tem-se novamente um resultado comprovativo da existência de ilhas úmidas no interior da mata e seu arredor, ou seja, há maior umidade presente no ar, quando comparada com dados do INMET. No cartograma da figura 12 , observa-se uma diferença de UR de até 15\% no interior da área pesquisada.

As variações diurnas de umidade ocorreram em concordância com as de temperatura, onde há mais calor durante o dia, há menos umidade e vice e versa. $\mathrm{Na}$ face leste da área, observou-se, assim como nos outros tipos de tempo, que a temperatura influenciou nos baixos índices de UR, e fez com que a parte da área estudada apresentasse os menores índices (pontos $\mathrm{A} \mathrm{e} \mathrm{B}$ ).

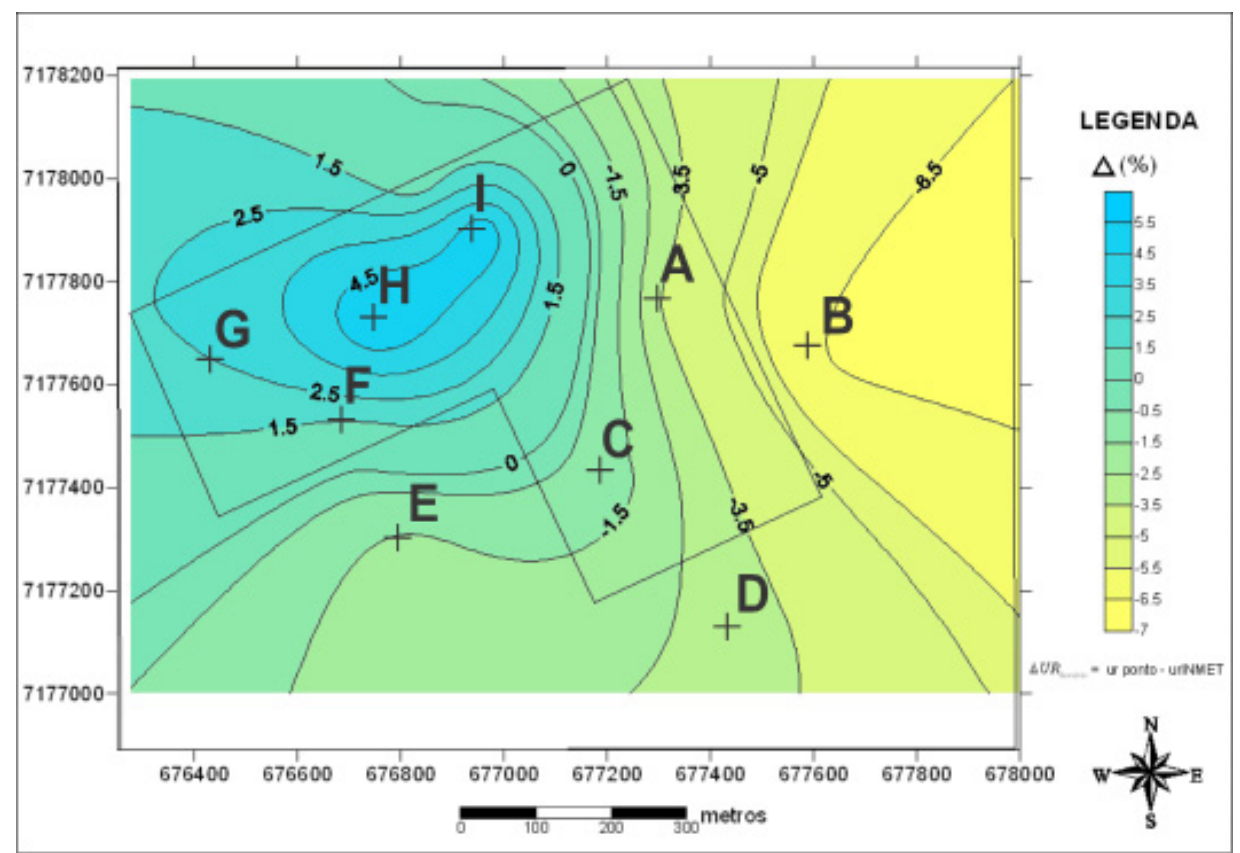

Figura I I. Isoígras associadas à mPA no horário das 9 horas 


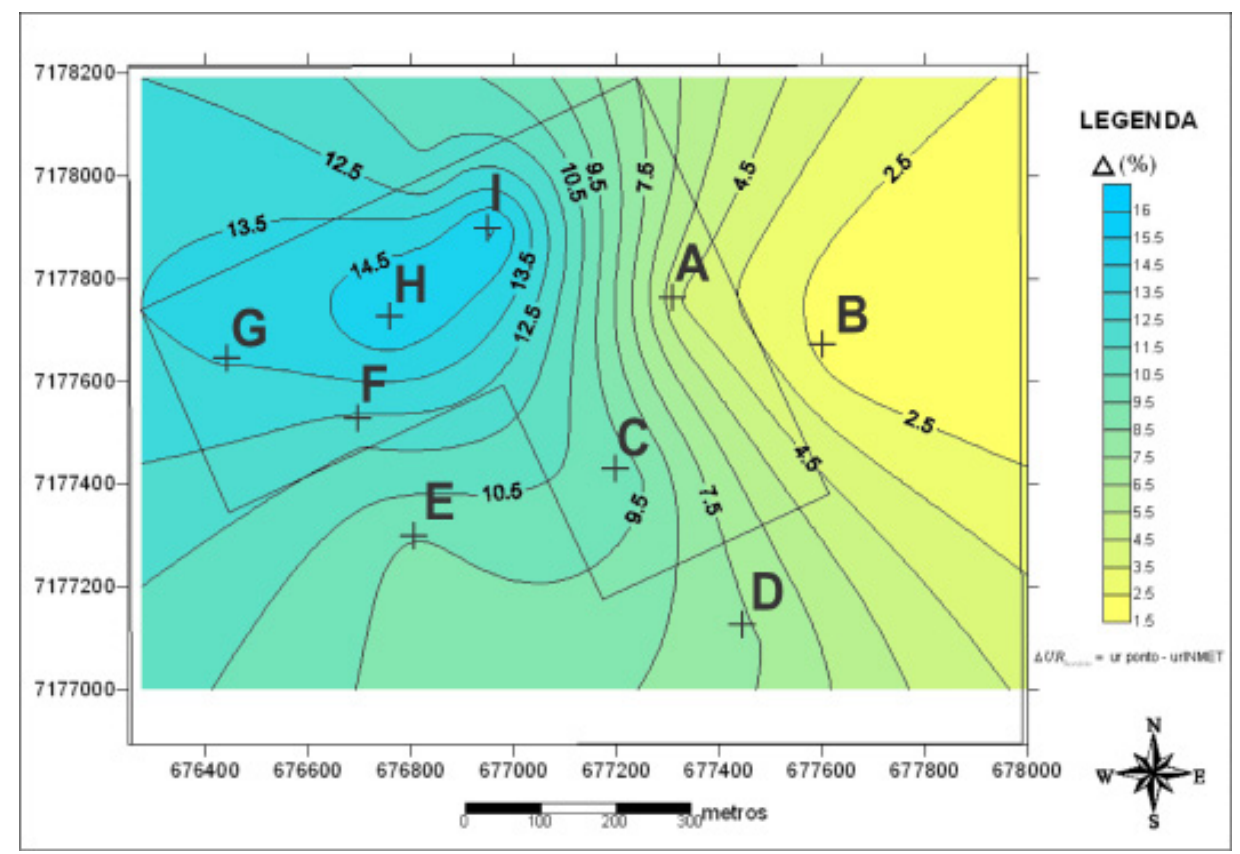

Figura I2. Isoígras associadas à mPA no horário das 15 horas

A UR destacada no horário das 21 horas, quando comparada com o horário das 15 horas, apresenta uma queda na variação, porque está sendo comparado com a estação padrão da cidade. Assim, a umidade relativa presente na estação aumentou devido ao rebaixamento da temperatura, diminuição do fluxo de veículos e resfriamento da camada superficial do solo. Observa-se ainda, na figura 13 , a pouca influência que a vegetação exerceu durante esse horário nas áreas entorno.

A frente fria que atingiu o Rio Grande do Sul no dia 8 (Figura 14), não obteve força suficiente para avançar sobre o continente, desviando-se para o oceano no dia 09, entretanto devido ao aquecimento e a mudança gradual na direção dos ventos em diferentes níveis da atmosfera, causou o aumento dos índices de instabilidade atmosférica sobre o leste paranaense.

Essa FPA que se afastou para o oceano provocou o avanço de ventos úmidos marítimo, deixando o céu nublado durante todo o dia 9, com chuva leve. A temperatura declinou consideravelmente devido à chegada da nova massa de ar polar conforme é visto na figura 15.

As condições do tempo apresentaram alterações devido à rápida passagem da frente fria e ao ingresso da massa de ar frio com intensidade moderada. As temperaturas registraram um ligeiro declínio nos dias 10 e 11 em consequência do avanço da mPA.

Observou-se, durante a atuação dessa massa, que ela apresentou características de massa Polar Velha, tropicalizando-se. Essa grande massa de ar seco facilitou a formação de nevoeiro ao amanhecer devido às temperaturas baixas, e registrou-se $o$ rebaixamento gradativo dos índices de umidade do ar, conforme mostra o gráfico da figura 16 , sendo possível visualizar índices inferiores a 45\% no INMET e 46\% na área de estudo, contudo 


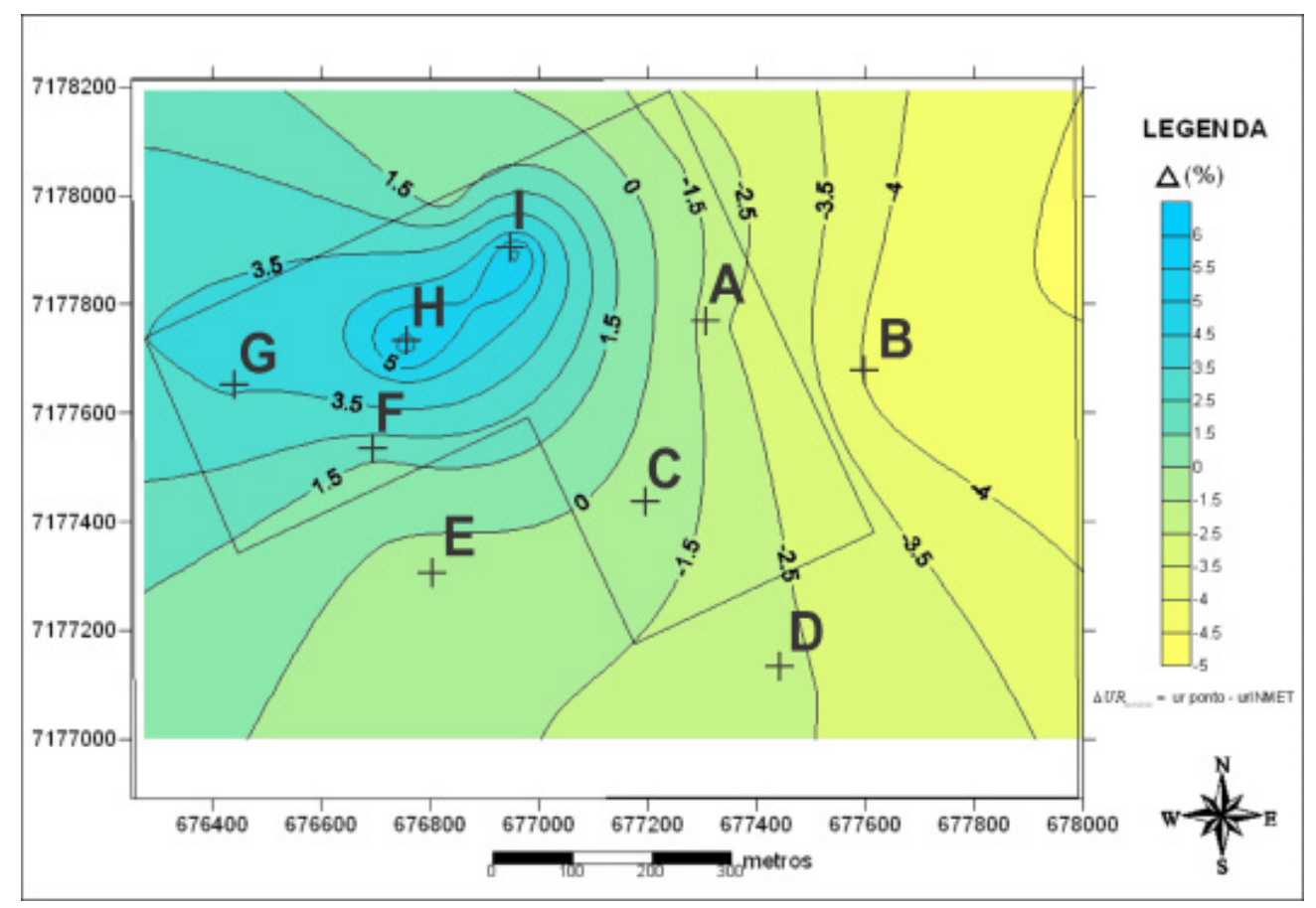

Figura 13. Isoígras associadas à mPA no horário das 21 horas
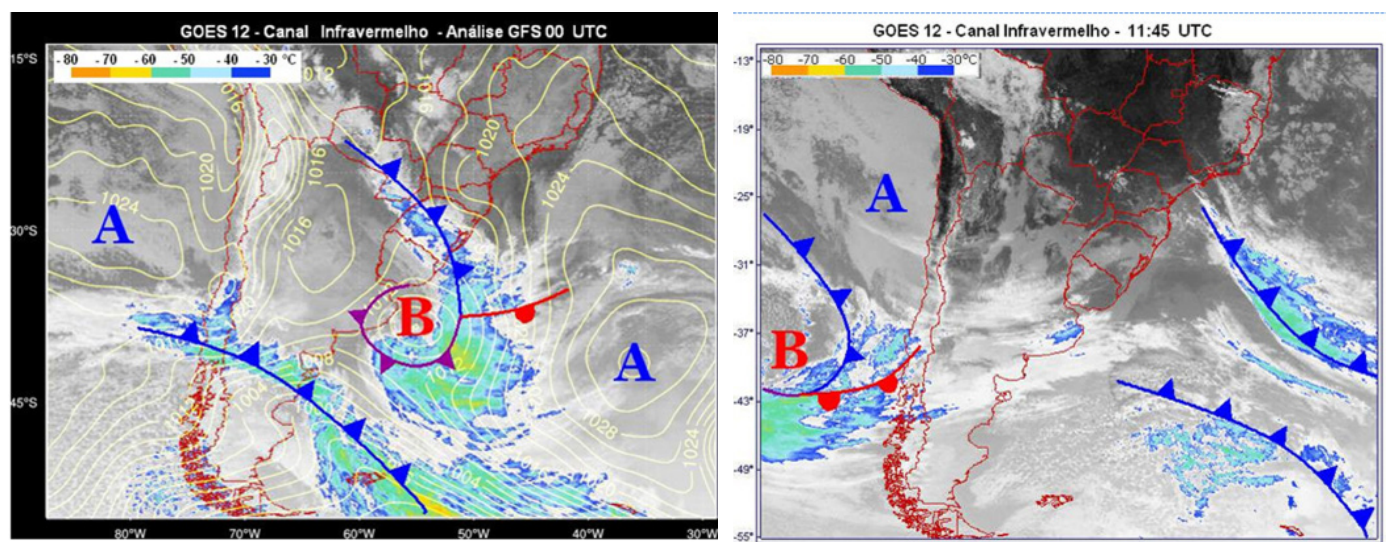

Figura 14. Imagem do Satélite GOES I2 - Canal Infravermelho - do dia 8 (esquerda) que descreve a atuação de uma massa de ar, no caso a mPA, sobre a região monitorada, entretanto observa-se o avanço de uma frente fria pelo RS o que causou aumento da instabilidade atmosférica . $\mathrm{Na}$ imagem do dia 9 (direita) observa-se que essa FPA desviou-se para o oceano.

Fonte: Simepar. Organizado pelo autor. 


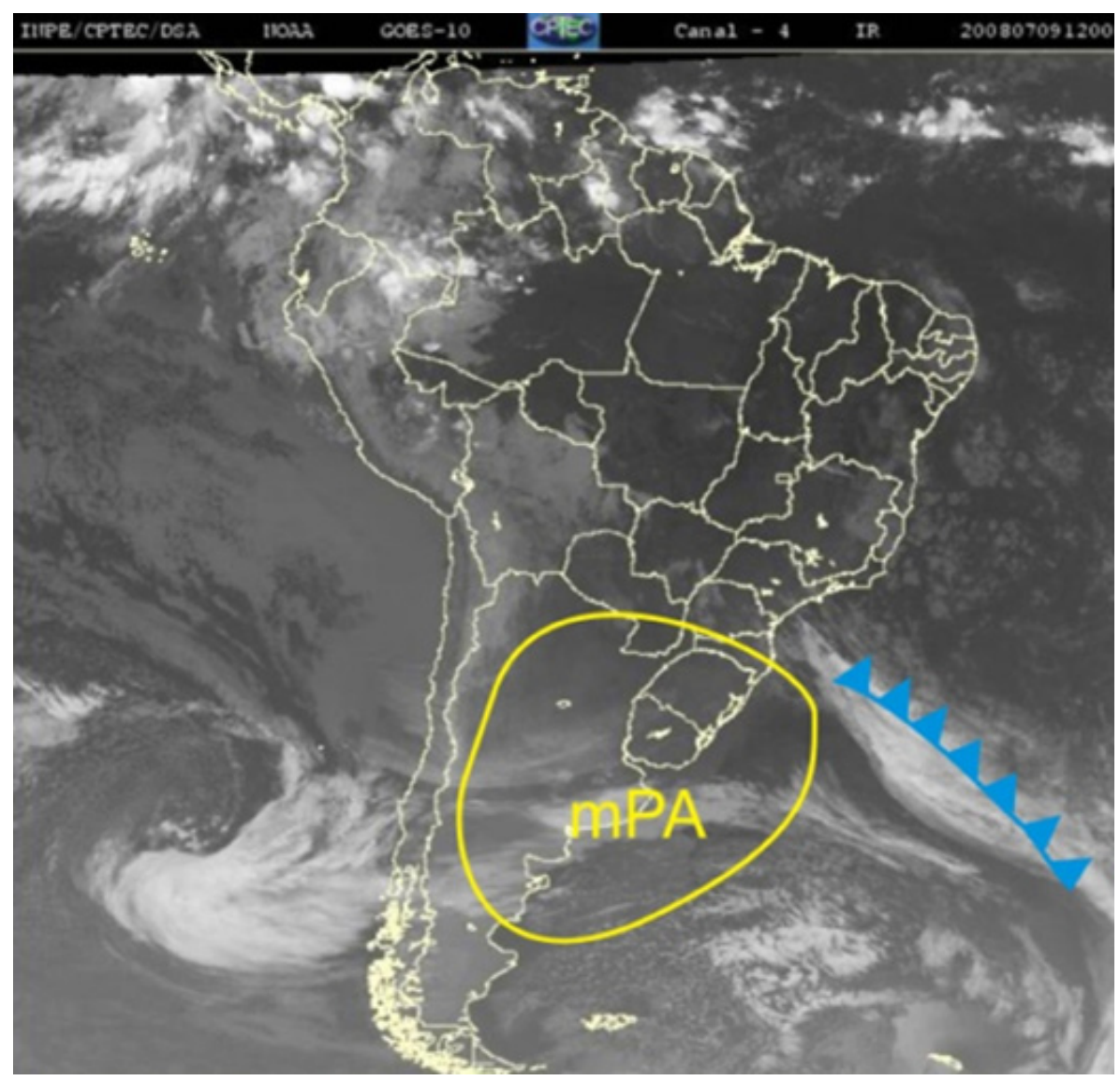

Figura 15. Imagem do Satélite GOES 10 - Canal Infravermelho - do dia 9 que destaca o avanço de uma nova mPA qual atuou sobre a região monitorada

Fonte: CPTEC e modificado pelo autor (2008).

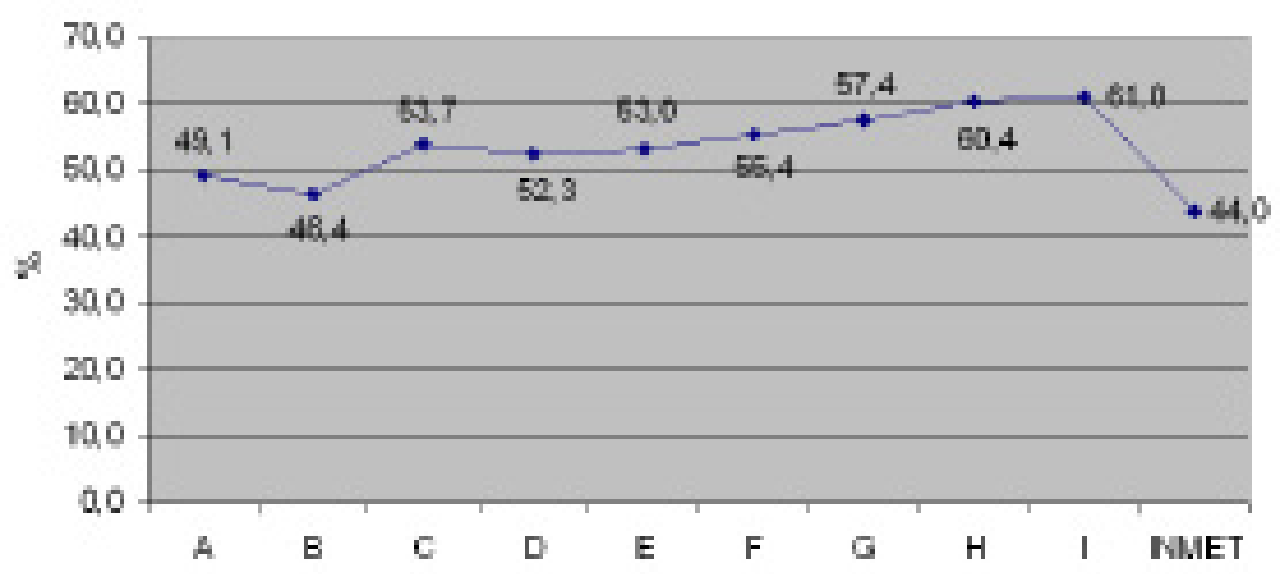

Figura 16. Valores absolutos de UR as 15 horas associada à mPA. 
No dia 25, após a passagem da uma FPA, o ingresso de uma nova massa de ar polar (Figura 17) favoreceu o declínio das temperaturas mínimas, sendo que as 21 horas do dia 25 , registrou-se $6,5^{\circ} \mathrm{C}$ nos pontos $\mathrm{He}$ I e $7,3^{\circ} \mathrm{C}$ na estação do INMET. Na medição das 15 horas do dia 26, as temperaturas apresentaram um aumento de $7{ }^{\circ} \mathrm{C}$, quando comparada com o horário sinótico anterior (09 horas) nos pontos monitorados.

Durante a coleta de dados, das 15 horas do dia 28 , os índices de umidade relativa do ar foram baixos na grande maioria dos pontos de monitoramento, atingindo índices que variaram de 30 a 48\%, conforme pode ser visto no gráfico da figura 18 . Nesse dia, na estação do INMET, registrou-se 26\% de UR, o qual foi o menor índice durante todo o experimento.

Com a baixa umidade, foi necessário atentar para o risco de incêndio florestal na área e, apesar dos índices serem destacadamente baixos, observou-se que no interior do bosque a vegetação influenciou na manutenção da umidade, bem como na área de entorno, de urbanização menos densa, como é o caso dos pontos $\mathrm{D}$ e $\mathrm{E}$, diferentemente dos pontos $\mathrm{A}$ e $B$ que apresentaram os menores índices da área.

A velocidade dos ventos durante a atuação da mPA foi significativa pela fraca intensidade com que atuaram, atingindo uma variação que não alcançou $1 \mathrm{~m} / \mathrm{s}$ quando comparada com a velocidade registrada pela estação padrão da cidade de Curitiba.

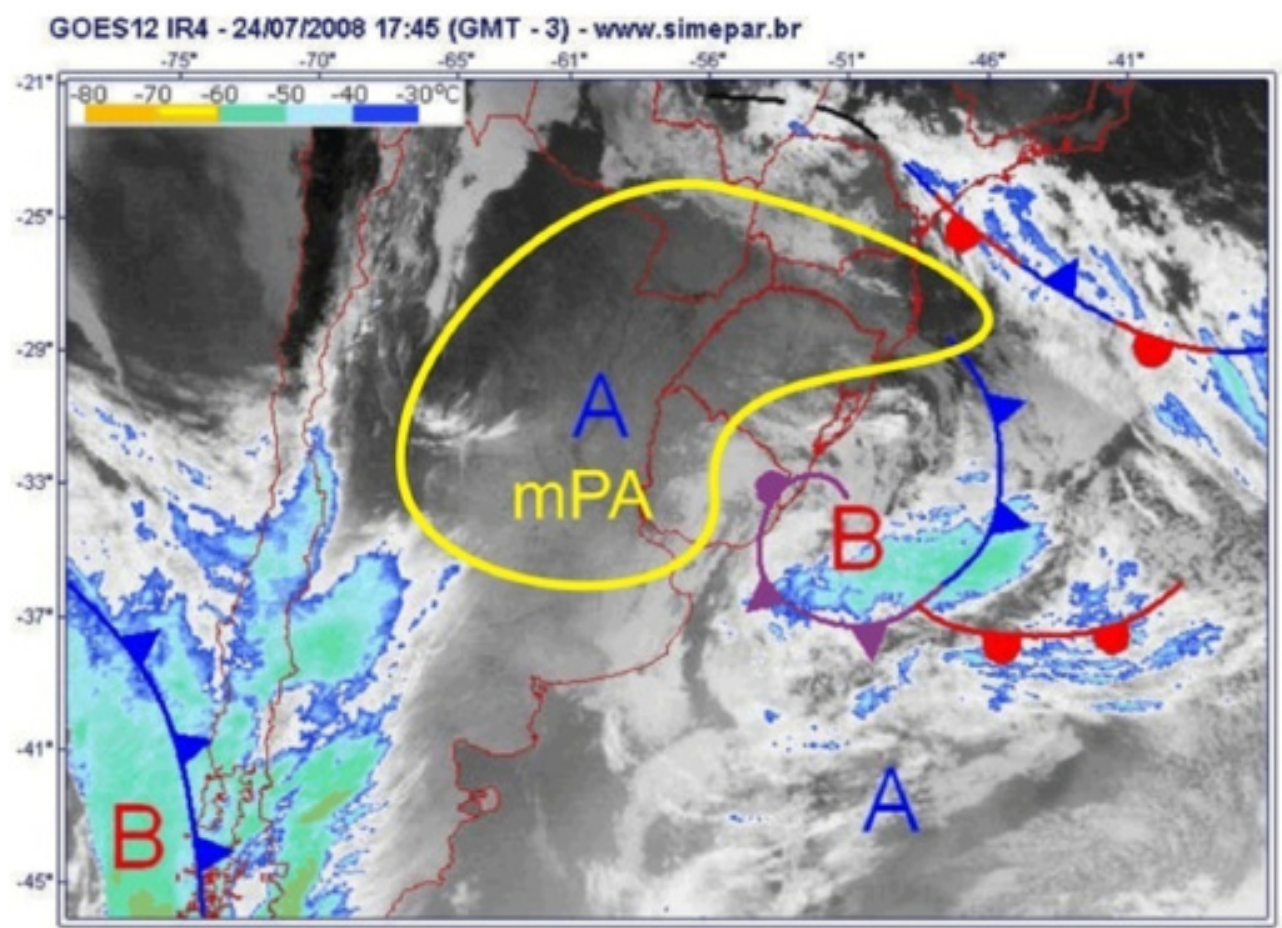

Figura I7. Imagem do Satélite GOES 12 - Canal Infravermelho - do dia 25 aponta para a atuação de uma nova massa de ar polar (mPA) na área pesquisada

Fonte: Simepar e modificado autor. 


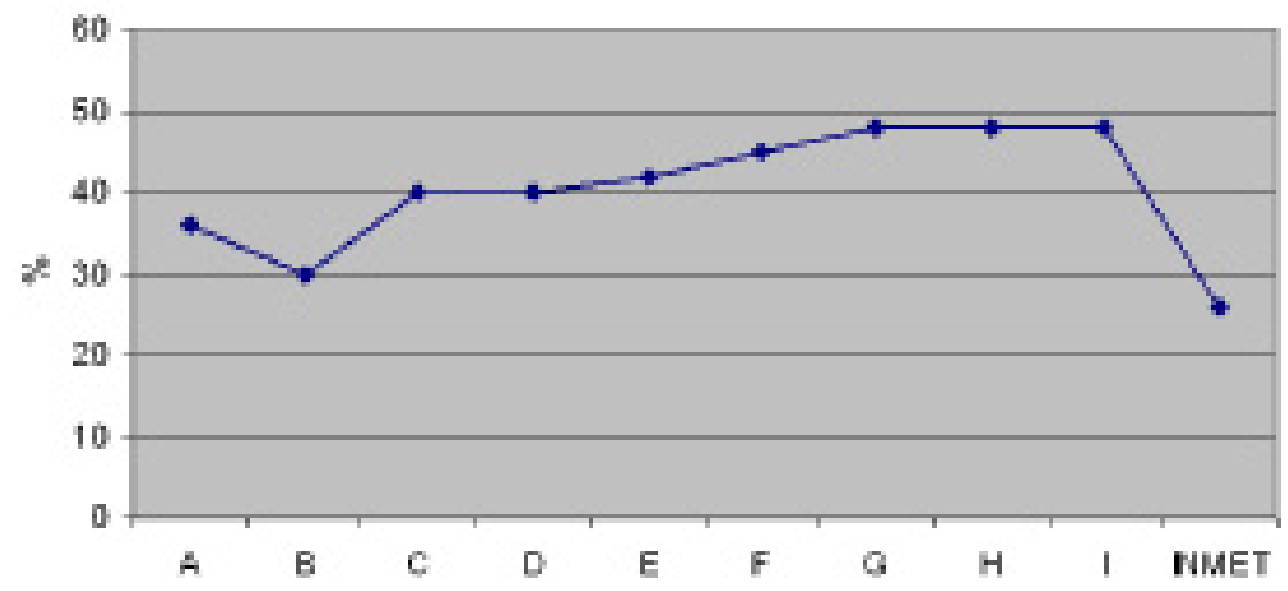

Figura 18. Valores absolutos de UR as 15 horas, associada à mPA do dia 28

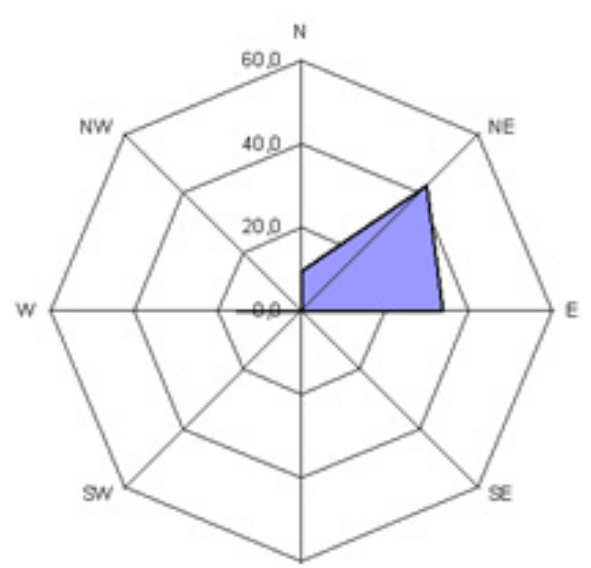

Figura 19. Direção dos ventos associados à mPA

\section{Considerações Finais}

O estudo elaborado mostra a importância dos tipos de tempo na configuração do campo térmico da área de estudo, sendo que para cada tipo há uma análise característica, pois os sistemas atmosféricos se comportam de maneira distinta.

Após as análises realizadas, verificouse que o aquecimento da superfície sob determinados tipos de tempo é significativo e indica que a urbanização e as atividades antrópicas interferem nos índices de temperatura local, ainda revelaram que, para cada tipo de tempo, nem sempre a relação da temperatura e umidade relativa ocorre de forma esperada e direta.

O trabalho apresentou resultados em que numa mesma situação de tempo, os locais sob influência de uma área vegetada se configuram de maneira oposta às regiões sob predomínio da urbanização, claramente visível durante a atuação da mPA.

O diagnóstico das condições sinóticas mostrou que julho (2008) foi atípico para um mês característico da estação inverno. Ocorreram sete dias sob o predomínio dos sistemas frontais (FPA), onze dias ficaram sob influência da massa de ar polar atlântica (mPA) e treze dias sob a forte predominância da massa de ar tropicalizada (mPV) o que interferiu diretamente na qualidade do ar, reduzindo os índices de umidade e aumentando as temperaturas.

A metodologia empregada nesta pesquisa apresentou aspectos positivos e negativos. Destacam-se no quesito das 
vantagens, a facilidade do transporte da estação móvel, sendo possível adentrar nas áreas de difícil acesso ou amplamente urbanizada, tendo em vista furtos e avarias numa possível instalação de estação fixa nos pontos de monitoramento.

O acesso diário aos dados do INMET, com a sua atualização automática, fazendo com que as variáveis coletadas no terreno pudessem ser comparadas logo após o trabalho é outro ponto singular.

Todavia, verificou-se neste estudo que a urbanização da área estudada provocou a redução da cobertura vegetal e das áreas de solo permeável, o que pode ter contribuí para o aumento dos índices de temperatura e consequente baixas umidades na área em que foram coletadas as variáveis.

\section{Referências}

AGUIAR, F. E. O.; SILVA, D. A. A importância das áreas verdes para o clima da cidade de Manaus. In: SIMPÓSIO BRASILEIRO DE CLIMATOLOGIA GEOGRÁFICA, 8., 2008, Alto Caparaó, MG. Anais.... Uberlândia: EDUFU, 2008. p.26-39.

CPTEC - Centro de Previsão do Tempo e Estudos Climáticos. Disponível em: <www.cptec. inpe.br> Acesso em : 1 a 31 jul. 2008.

DANNI-OLIVEIRA, I. M. Considerações sobre a poluição do ar em Curitiba-PR face a seus aspectos de urbanização. RA'EGA, Curitiba, n.4, p. 101-110. 2000.

EMBRAPA. Mapas de Solos do Paraná. Rio de Janeiro: RJ, 1999. Escala 1: 600.000.

INMET - Instituto Nacional de Meteorologia. Disponível em: <www.inmet.gov.br > Acesso em: 1-31 jul. 2008.

LOMBARDO, M. A. A Ilha de Calor nas Metrópoles: o exemplo de São Paulo. São Paulo: HUCITEC, 1985.

LOWRY, W. The climate of cities. Scientific American, v. 217, n.2, 1967.

MENDONÇA, F. A. Clima e planejamento urbano em Londrina: proposição metodológica e de intervenção urbana a partir do estudo do campo termo-higrométrico.In: MONTEIRO, C. A. F.; MENDONÇA, F. (Org.). Clima Urbano. São Paulo. 2003. p.93 - 120.

MENDONÇA, F. A.; DANNI-OLIVEIRA, I. Climatologia: noções básicas e climas do Brasil. São Paulo: Oficina de Textos, 2007.

MENDONÇA, R. S. R.; ASSIS, E. S. Conforto térmico urbano: Estudo de caso do bairro Floresta em Belo Horizonte, Minas Gerais.Belo Horizonte: EA-UFMG, 1999. 10p.

MONTEIRO, C. A. F. Teoria e clima urbano. 1975. Tese (Livre-docência) - Universidade de São Paulo, USP, São Paulo, 1975. 
SALATI, E.; JUNK, W. J.; SHUBART, E. O. R.; OLIVEIRA, A. E. Amazônia: desenvolvimento, integração e ecologia. São Paulo: Brasiliense, CNPq, 1983.

SIMEPAR - Sistema Meteorológico do Paraná. Disponível em: <http://www.simepar.br> Acesso em: 1 a 31 jul. 2008.

740 Ambiência - Revista do Setor de Ciências Agrárias e Ambientais V. 8 Ed. Especial - I Novembro2012 